
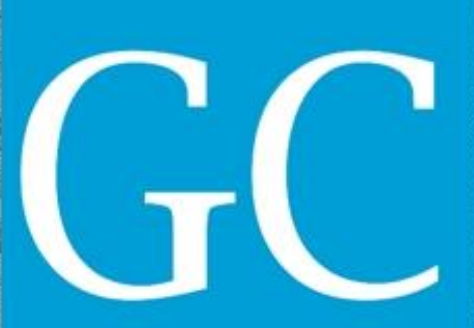

Revista Nacional de Gerenciamento de Cidades

\title{
Pagamento por Serviços Ambientais: levantamento bibliométrico nos últimos dez anos
}

Payment for Environmental Services: bibliometric survey in the past ten years

Pago por Servicios Ambientales: levantamento bibliométrico en los últimos diez años

Joice Machado Garcia

Mestranda e bolsista CAPES em Sistema de Infraestrutura Urbana, PUC-Campinas, Brasil joiice_garcia@hotmail.com

Regina Márcia Longo

Docente Permanente do Programa de Pós-graduação em Sistemas de Infraestrutura Urbana, PUC-Campinas, Brasil regina.longo@puc-campinas.edu.br 


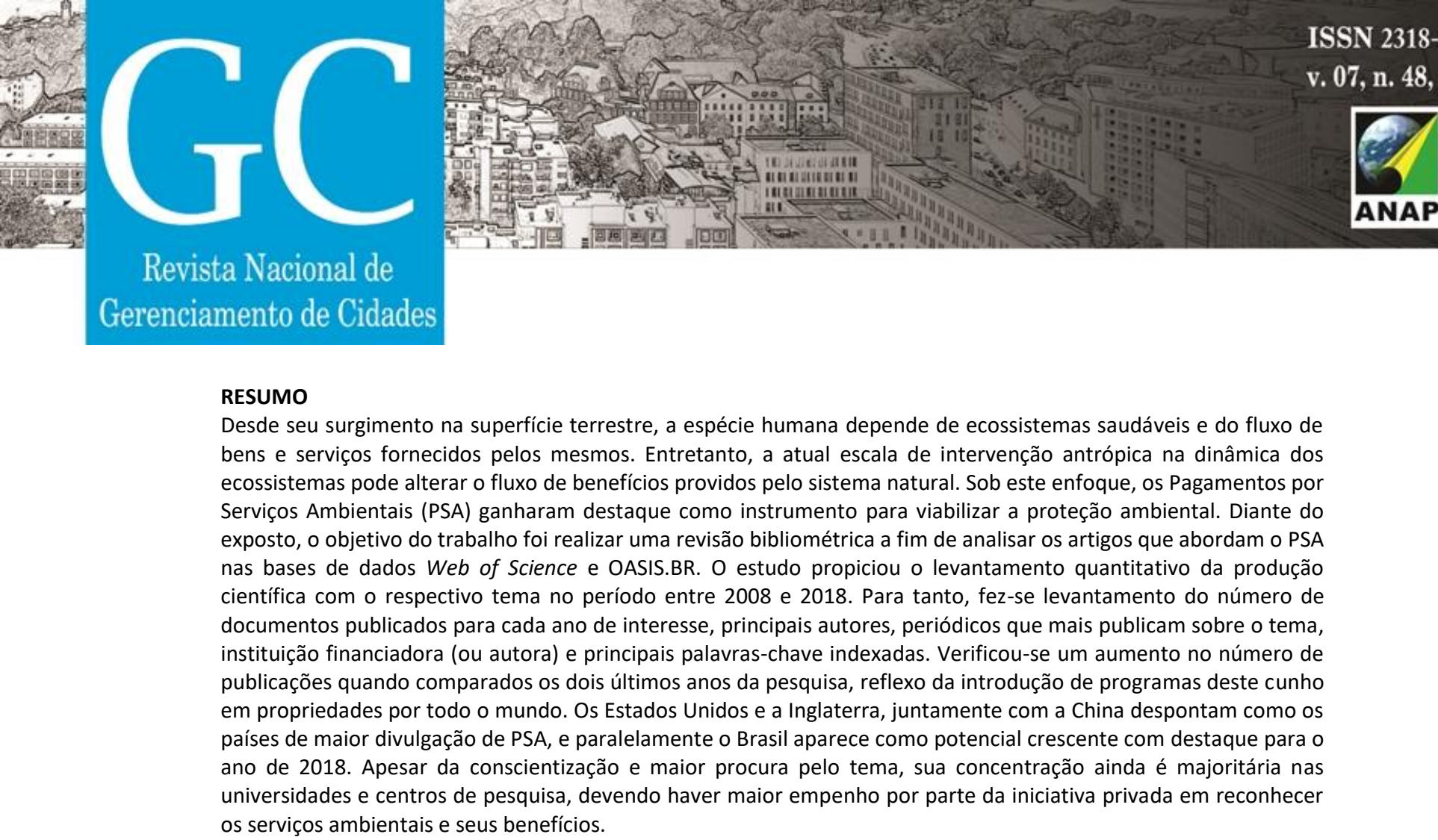

PALAVRAS-CHAVE: Serviços Ecossistêmicos. Qualidade Ambiental. PSA.

\section{ABSTRACT}

Since its emergence on the earth's surface, the human species depends on healthy ecosystems and the flow of goods and services provided by them. However, the current scale of anthropogenic intervention in ecosystem dynamics can alter the flow of benefits provided by the natural system. Under this approach, Payments for Environmental Services (PSA) gained prominence as an instrument to enable environmental protection. In view of the above, the objective of the study was to perform a bibliometric review in order to analyze the articles that address PSA in the Web of Science and OASIS.BR databases. The study provided a quantitative survey of the scientific production with the respective theme in the period between 2008 and 2018. To do so, a survey was made of the number of documents published for each year of interest, the main authors, the most published periodicals on the subject, the institution funder (or author) and key indexed keywords. There was an increase in the number of publications compared to the last two years of the research, reflecting the introduction of programs of this kind in properties worldwide. The United States and Britain, together with China, are emerging as the countries with the highest PSA disclosure, and in parallel, Brazil appears as a growing potential with a highlight for the year 2018. Despite the awareness and greater search for the subject, its concentration is still in universities and research centers, and there should be greater commitment on the part of the private sector to recognize environmental services and their benefits.

KEYWORD: Ecosystem Services. Environmental Quality. PES.

\section{RESUMEN}

Desde su surgimiento en la superficie terrestre, la especie humana depende de ecosistemas sanos y del flujo de bienes y servicios proporcionados por los mismos. Sin embargo, la actual escala de intervención antrópica en la dinámica de los ecosistemas puede alterar el flujo de beneficios provistos por el sistema natural. En este enfoque, los Pagos por Servicios Ambientales (PSA) ganaron destaque como instrumento para viabilizar la protección ambiental. Ante el expuesto, el objetivo del trabajo fue realizar una revisión bibliométrica a fin de analizar los artículos que abordan el PSA en las bases de datos Web of Science y OASIS.BR. El estudio propició el levantamiento cuantitativo de la producción científica con el respectivo tema en el período entre 2008 y 2018 . Para ello se hizo el levantamiento del número de documentos publicados para cada año de interés, principales autores, periódicos que más publican sobre el tema, institución financiadora (o autora) y principales palabras clave indexadas. Se verificó un aumento en el número de publicaciones cuando se compararon los dos últimos años de la investigación, reflejo de la introducción de programas de este cuño en propiedades por todo el mundo. Los Estados Unidos e Inglaterra, junto con China, se desprende como los países de mayor difusión de PSA, y paralelamente Brasil aparece como potencial creciente con destaque para el año 2018. A pesar de la concientización y mayor demanda por el tema, su concentración todavía es mayoritaria en las universidades y centros de investigación, debiendo haber mayor empeño por parte de la iniciativa privada en reconocer los servicios ambientales y sus beneficios.

PALABRA-CLAVE: Servicios Ecosistémicos. Calidad Ambiental. PSA. 


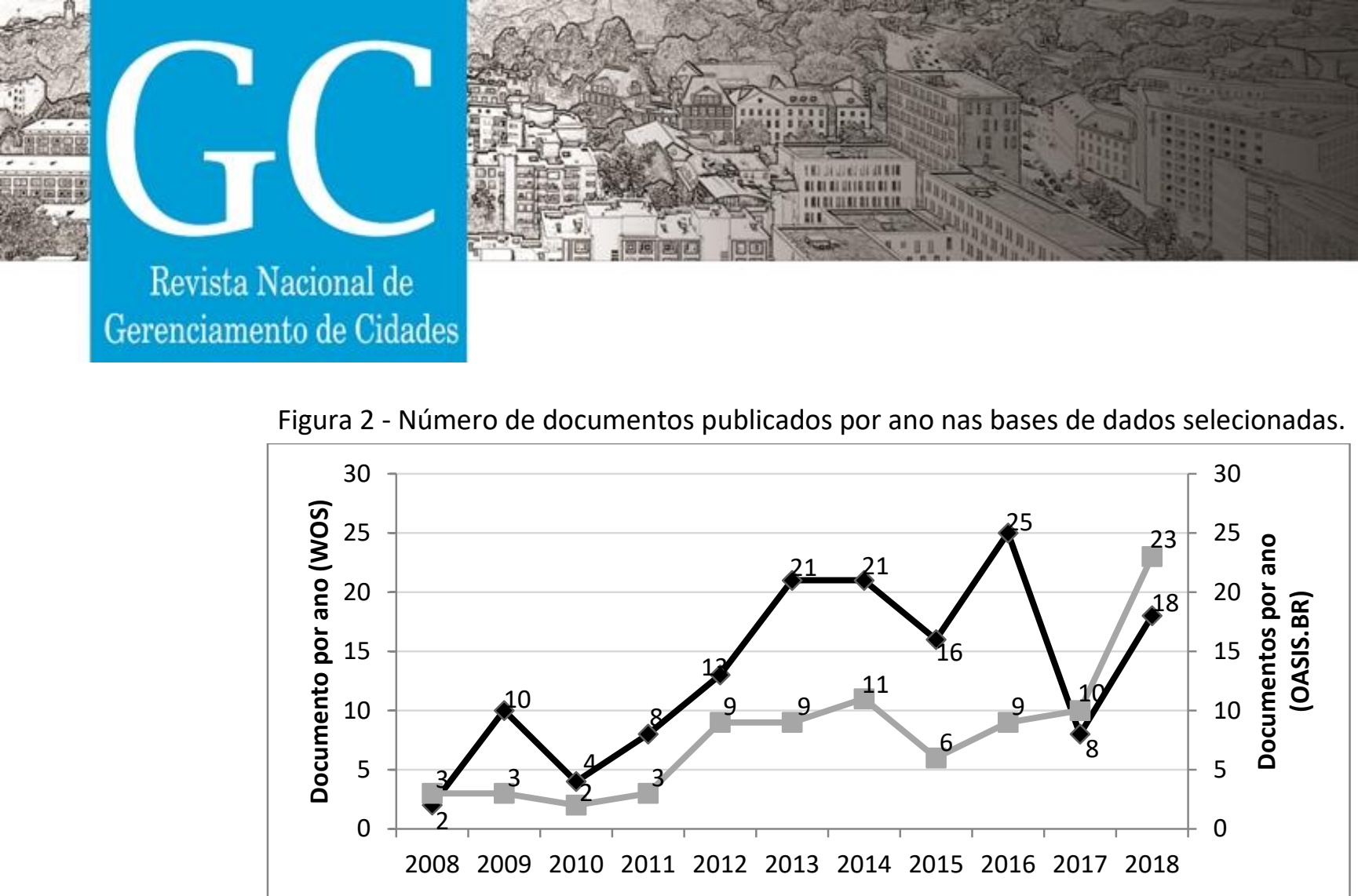

Fonte: AUTORES, 2019.

O mecanismo de PSA no Brasil foi introduzido na legislação federal no capítulo décimo da Lei 12.651/2012, com alterações introduzidas pela Lei 12.727/2012, justificando o primeiro pico no ano de 2012 (GODECKE; HUPFFER; CHAVES, 2014). Até o presente, não há um programa de PSA federal, apesar de o programa PROAMBIENTE administrado pelo Ministério do Meio Ambiente ter algumas características de PSA. A Agência Nacional de Águas (ANA) também atua com projetos de PSA por meio do fornecimento de suporte técnico aos usuários que queiram desenvolver programas de PSA-Água, permitindo com que os programas de PSA no país sejam majoritariamente hídricos (PAGIOLA; VON GLEHN; TAFFARELLO, 2013).

A Figura 3 apresenta os autores mais citados e com maior número de publicações nas plataformas consultadas. Em ambas as situações foi possível ver o destaque de certos autores, com número de publicações considerável, e portanto, "nomes referências" no panorama mundial de PSA.

Figura 3 - Número de documentos publicados por autor nas bases de dados selecionadas.

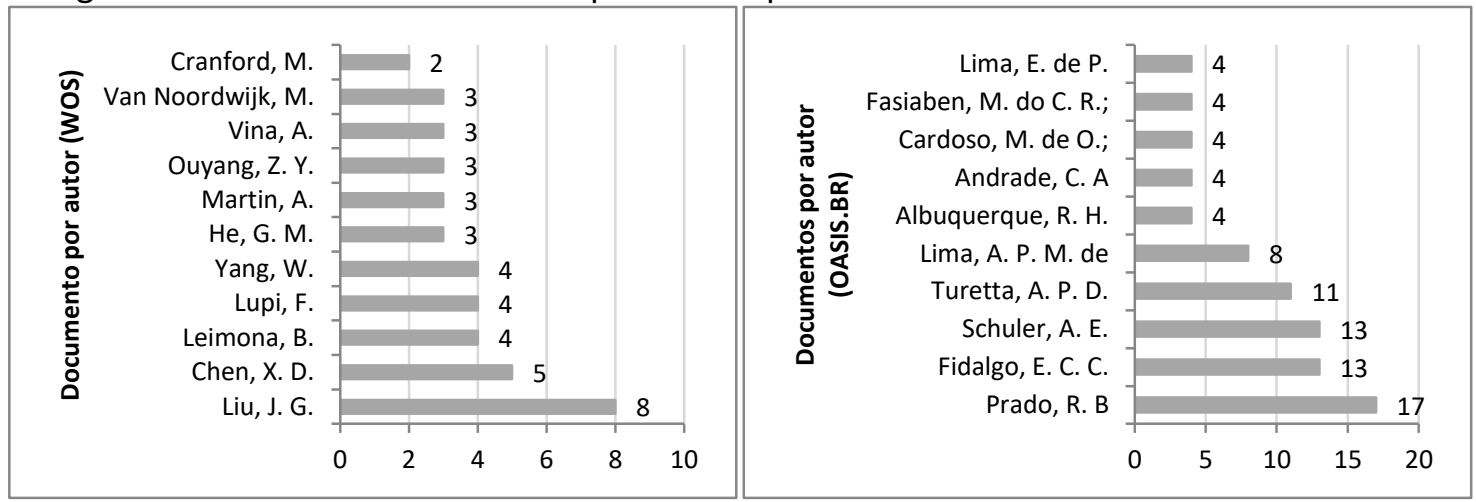

Fonte: AUTORES, 2019. 
